\title{
Hvorfor samtalen ikke er demokratiets sjæl
}

\author{
Af Michael Schudson
}

Medie- og kommunikationsforskningen har ofte opfattet samtalen, der fores ansigt-til-ansigt, som en hjornesten $i$ den demokratiske proces. Denne opfattelse stammer bl.a. fra medieforskeren Fames Carey, der selv har varet inspireret af den amerikanske filosof John Dewey. I denne artikel presenterer Michael Schudson en kritik af, hvad han kalder den romantiske forestilling om samtalen. Samtalen ansigt-til-ansigt har varet lige så meget $i$ hojsedet $i$ aristokratier som $i$ demokratier, og der er faktisk to distinkte og modsatte idealer for samtale: den selskabelige samtale og den problemlosende samtale. Samtalen, der tjener demokratiet, er ikke kendetegnet ved egalitarisme, men ved normstyrethed og offentlighed, ikke ved spontanitet men ved haflighed, og ikke ved dens forrang eller overlegenhed i forhold til trykte medier, radio eller tv, men ved dens nodvendige afhangighed af dem. Der argumenteres for, at institutioner og demokratiske normer giver anledning til demokratiske samtaler, snarere end at samtalens iboende demokrati forer til politisk demokratiske normer og institutioner. Artiklen er oversat af Stig Hjarvard.

Begreber som »det civile samfund « og »offentligheden« har sat fokus på »talens« karakter som et konstituerende træk ved demokratiet. Når Jürgen Habermas skriver, at »en del af offentligheden skabes i enhver samtale, i hvilken private individer samles for at skabe en offentlig forsamling « (Habermas, 1974: 79), tildeles samtalen en overordentlig vigtig politisk rolle. Hvis demokrati er ledelse gennem diskussion, som det ofte er blevet kaldt, eller mere præcist »ledelse gennem rationel og fri offentlig diskussion mellem juridisk lige borgere«, må samtalen ligge demokratiets hjerte nær.'

Dette var i hvert fald John Deweys opfattelse. For ham var tale et centralt element i det demokratiske liv. Den vigtigste forudsætning for revitalisering af det offentlige liv, skrev han i 1927, er »forbedringen af metoderne og betingelserne for debat, diskussion og overtalelse. Dette er problemet for offentligheden« (Dewey, 1927: 208). Uagtet hans store autoritet, er det denne påstand, jeg ønsker at kritisere. Jeg gør det i en forsonlig tone, idet jeg kritiserer en opfattelse, som jeg selv finder meget tiltrækkkende. Men jeg synes også, at den har været misvisende, måske endda i faretruende grad.

\section{Samtalens plads i demokratiet}

Man behøver ikke lede længe i dag for at finde synspunkter, der placerer samtale i centrum af det demokratiske liv. Den literære kritiker David Simpson (1997) taler ligefrem om en »samtalens »kult«« i nutiden. Der er en veritabel besættelse af begrebet. Man finder det overalt i det akademiske landskab - i postmodernistisk filosofi, i kommunitaristisk social kritik, i bevægelsen for »public journalism « og mange andre steder. Man finder det blandt frisindede kritikere af massemedierne og hos det diskursive demokratis filosoffer. Begrebet står centralt i Richard Rortys kritik af videnskabelig og filosofisk erkendelse. Hvad man kan »vide« er for Rorty kun, hvad vi kan nå frem til i en vedvarende samtale med andre mennesker, snarere end i et møde med en natur hinsides menneskelig interaktion. Både Rorty, Michael Oakeshott og Hans-Georg Gadamer tager afsæt i samtale som en model for videnstilegnelse. Hvad vi er vidne til, har Simpson bemærket, er »fremkomsten af samtalen som ideal i den postmoderne kultur« (Simpson, 1995: 47). 
I kommunikationsforskningen har James Carey leveret et særligt overbevisende bidrag til at placere samtalen i centrum af det offentlige liv og til at lade genskabelsen af en offentlighed blive en hovedopgave for et demokratisk samfund. Offentligheden, skriver han, er »en gruppe af fremmede, der samles for at diskutere nyhederne (Carey, 1995: 381). Det er »et samfund af konversationsudøvere eller debattører, der er afhængige af bogtrykkerkunsten for udbredelse af deres idéer « (Carey, 1995: 381). Dette var det store ideal om offentligheden - og ifølge Careys opfattelse havde det på samme måde, som også Habermas ser det, baggrund i virkeligheden. Denne »samtalende offentlighed« var med Careys formulering »et diskuterende og disputerende publikum uafhængig af både presse og stat«, og den er »i vor tid i stort omfang blevet berøvet sin saft og kraft« (Carey, 1995: 383). I takt med at journalistikken i løbet af det tyvende århundrede $\mathrm{i}$ kraft af sine professionelle normer blev mere »objektiv«, gik forholdet mellem presse og publikum i opløsning. »Pressen befordrede eller tilskyndede ikke længere til en offentlig samtale, for den offentlige samtale var forsvundet« (Carey, 1995: 389). Pressen skabte ikke længere baggrunden for udøvelse af samtalens centrale hverv; enhver tilbagebleven samtale »blev iscenesat af pressen, som mente sig i besiddelse af bedre viden og undersøgelsesmetoder til at afdække, hvad der faktisk skete« (Carey, 1995: 389). Ifølge Carey var den uafhængige journalistik - stærkt hjulpet af tv - med til at ødelægge de politiske partier, samtidig med at opinionsundersøgelser bidrog til at tilsløre den ægte offentlige mening. Den offentlige arena svandt ind, og borgere havde ikke mange andre muligheder end at blive »forbrugere af politik eller flygte fra den «(Carey, 1995: 391). Se også Carey (1987).

Men hvad er dette ideal om samtalen som den demokratiske tilværelses inderste sjæl - eller hvad var eller kunne det blive? Skal vi forestille os, at det udgør en form for social tilværelse, der er spontan og fri? Dette synes at være et vigtigt element i, hvad der gør samtalen til et centralt anliggende. Men det vil være forkert at antage, at det spontane også er det autentiske og sande. En fokusering på det spontane drejer opmærksomheden væk fra de redskaber, som demokratiet behøver - i særdeleshed fjerner det opmærksomheden fra den kendsgerning, at demokratiet er et redskab. Jeg vil argumentere for, at demokratisk tale ikke er grundlæggende spontan, men derimod fundamentalt regelstyret, grundlæggende civil og i modsætning til den slags samtaler, der ofte nyder høj anseelse for deres frihed og åndfuldhed, er den basalt set orienteret mod problemlosning.

Skal vi antage, at samtale er præget af ligeværdighed? Det er ikke nødvendigvis tilfældet. Det enkelte individ må være i besiddelse af »kulturel kapital« for at kunne deltage effektivt i en samtale. Man kan endda hævde, at det reelle forhold mellem tale og egalitet ikke består i beslægtethed, men derimod udgør et paradoks. Jo mere tale finder sted blandt personer, der vitterligt er lige, desto mere vil talen undlade at gøre antagelserne klare, undlade at redegøre for præmisser, ophøre med at være tilgængelig for alle og undertiden ligefrem forstumme. Antagelsen om lighed i samtale bortleder opmærksomheden fra det fundamentale problem, der knytter sig til medlemskab af et demokrati, nemlig at nogle er indenfor og andre udenfor, og på denne måde fjerner det opmærksomheden fra de regler, der gør demokrati muligt for en pluralistisk snarere end homogent sammensat befolkning. Hvad der kendetegner demokratisk tale, er for mig at se ikke lighed, men offentlighed. Demokratisk tale er ikke nødvendigvis egalitær, men til gengæld i bund og grund offentlig, og hvis dette indebærer, at demokratisk tale finder sted mellem mennesker med forskellige værdier og baggrunde, er den også udpræget ubehagelig.

Forestillinger om samtale i den vestlige tradition kan i hvert fald spores tilbage til Cicero, der skrev, at den private samtale skulle være frit løbende, uden følelser, fri for sladder om personer, der ikke er tilstede, og at den skulle inkludere alle og tillade alle at bidrage. I forlængelse af Cicero finder man i den tidligt moderne italienske, franske $o g$ britiske litteratur med gode råd om samtale en fremhævning af samarbejdsprincippet og lighedsaspektet som karakteristisk for den ideale samtale. Det var forkert at afbryde, som en fransk instruktionsbog fra det 17. århundrede fremførte, ligesom det var forkert at monopolisere samtalen. Man tilskyndede samtidig til spontanitet, også selvom den ironisk nok måtte forberedes. En autoritet på området anbefalede »tøven og endog lejlighedsvis klodset optræden for at fastholde illusionen af spontanitet . $^{2}$

De lighedsorienterede anvisninger indgik dog i en kontekst. Der blev også givet råd om, hvordan man talte til éns over- og underordnede, ligesom 
det var overflødigt at nævne, at nogle personer stod helt uden for samtalen. Jo, man tilskyndede til spontanitet; men man gav også råd om, hvordan man skabte den. Jo, man opfordrede til samarbejde; men de tidlige vejledninger anerkendte også konkurrenceelementet i samtalen og ønsket om at føre sig frem. Historikeren Peter Burke (1995) konkluderer, at »en overordnet teori om samtalen bør diskutere spændingen og balancen mellem de konkurrenceprægede og samarbejdende principper, mellem lighed og hierarki samt mellem spontanitet og indstuderethed, snarere end at lægge vægten på det første led i alle disse par« (Burke, 1995: 92).

At anerkende en spænding mellem samtalens principper er én måde, hvorpå vi kan nå til en mere sammenhængende og realistisk opfattelse af samtale. Som alternativ til dette vil jeg fremlægge det synspunkt, at to ganske forskellige samtaleidealer er blevet flettet sammen og forvekslet. Det ene ideal kan vi kalde den selskabelige samtalemodel, det andet den problemløsende model. Det afgørende kendetegn ved det selskabelige ideal er dets insisteren på, at samtalen ikke er nyttebetonet. Som den politiske filosof Michael Oakeshott skrev, er samtalens mål ikke udspørgen, og der er ikke nogen stræben efter en konklusion. Det er hverken afgørende at informere eller overtale. Ræsonnementet »er ikke i højsædet«, og samtale »udgør ikke noget argument«. Samtale har ikke noget mål ud over sig selv. Den er et »ikke-indøvet intellektuelt eventyr«, og - »som tilfældet er med hasardspil - ligger dens betydning hverken i at vinde eller tabe, men i satsningen « (Oakeshott, 1962: 198; se også Shapin, 1994: 114-121). ${ }^{3}$

I Oakeshotts diskussion af samtale er den vigtigste del måske hans forestilling om, at hvad et menneske i en given alder arver af menneskelig civilisation ikke er videnskab, teknologi eller en akkumuleret fond af viden, men en »samtale, der tog sin begyndelse i urskoven, og som udviklede sig og blev mere artikuleret i løbet af århundredernes gang. Det er en samtale, der både føres i offentligheden og inden i hvert eneste individ... Det er evnen til at deltage i denne samtale, og ikke evnen til at ræsonnere overbevisende, til at gøre opdagelser om verden og til at udtænke en bedre verden, der adskiller mennesket fra dyret og det civiliserede menneske fra barbaren « (Oakeshott, 1962: 198). Ifølge denne model er samtalen orienteret mod glæden ved at interagere med andre gennem selve samtalen. Den er derfor social i forhold til sin samtid, men som en del af en fortløbende samtale over tid, hvori den inddrager materiale fra en lang menneskelig tradition, er den også social i historisk forstand.

I modsætning hertil vil man i den problemløsende samtaleopfattelse begrunde samtalen ved dens praktiske sammenhæng med artikuleringen af fælles målsætninger. John Dewey skrev, at folkeafstemning, flertalsstyre og andre indikatorer for demokrati garanteres af det faktum, at »de involverer en konsultation og diskussion, der afdækker sociale behov og problemer« (Dewey, 1927: 206). Det vigtigste problem, som moderne demokratier står over for, er »forbedringen af metoderne og betingelserne for debat, diskussion og overtalelse. Dette er problemet for offentligheden« (Dewey, 1927: 208). For Dewey kunne demokratiet ikke eksistere uden deltagelse, og samtale er deltagelsens adelsmærke. »Forbindelserne mellem øret og de livsvigtige og udadvendte tanker og følelser er mere varierede, end hvad øjet kan præstere. Synet er en tilskuer; hørelsen er en deltager«(Dewey, 1927: 219). ${ }^{4}$

På trods af, at man i Careys tilfælde fornemmer hans tiltrukkethed af den rene fornøjelse ved samtalen, er der hos ham en tilsvarende fremhævning af samtalen som den arbejdsplads, hvor demokratiet opstår, hvis det da ellers overhovedet realiseres. For Carey er samtale striden om nyhederne, diskussionen om dagens emner. Det er den daglige kontrovers, ud af hvilken en demokratisk offentlighed skaber sig selv. Carey er i nogle henseender kritisk over for Dewey, specielt hvad angår hans manglende evne til at gennemtænke spørgsmålet om magtens tilstedeværelse i samtalen, og Careys mistro til eksperter stemmer ikke overens med Deweys tro på videnskaben som en fundamental vidensressource for demokratiet. Men Careys indsats i kommunikationsforskningen har alt i alt været en advokatur for relevansen af Deweys visioner for vort nuværende samfund. (Se Carey 1989: 6988).

Såvel den selskabelige som den problemløsende model for samtale understreger ligeværdigheden mellem deltagerne i samtalen. I selve samtalens udførelse hersker der lighed, høflighed og fairness. Men adgangstegnet til samtalen er forskelligt. Den selskabelige model fremhæver dannelse og følsomhed; samtaleparterne bør udvikle en subtil fornemmelse for levende, underholdende og gen- 
sidig tale. I modsætning hertil fokuserer den problemløsende model på argumentet, deltagernes evne til at formulere og svare på påstande om verdens faktiske tilstand, og hvordan den burde være. Den selskabelige model ser samtale som et mål i sig selv, en æstetisk fornøjelse. Den problemløsende model ser samtale som et middel i den gode ledelses tjeneste. Stærkere formuleret opfatter den selve samtalen som en model for god ledelse. Den selskabelige konversations kompetente deltager er i besiddelse af færdigheder eller evner som sproglig behændighed, åndfuldhed og selve evnen til selskabelighed. Deltageren i den problemløsende samtale er i besiddelse af fornuft. Som den politiske teoretiker William Galston formulerer det, er fornuften både »villigheden til seriøst at lytte til en flerhed af synspunkter« og »villigheden til at fremsætte ens egne synspunkter på en forståelig og oprigtig måde som grundlag for en overtalelsens politik« (Galston, 1991: 227).

Samtalens helbredende og interaktive karakter gør den særligt passende som model for såvel selskabelighed som offentligt ræsonnement. Det samme gør dens grundlæggende samarbejdende egenskab. Selv i et skænderi er der en gensidig understøttelse - om ikke andet så af en overenskomst om fortsat at være involveret, om at forblive fokuseret på den anden person, om på den ene side ikke at opgive talen til fordel for stokke og sten, og om på den anden side ikke at ty til den »tavse skulder«. Selv i tilfælde af en fjendtlig ordveksling bliver filosoffen Paul Grices (1975/1989) »samarbejdsprincip « ofte respekteret, d.v.s. at deltagerne taler i henhold til »det accepterede formål for og retning af den samtalemæssige udveksling«, de deltager i.

I den selskabelige samtale skaber talens interaktive involvering de kvaliteter, man kender fra et varieret spil som eksempelvis skak, hvor der er mange begrænsninger på de enkelte træk, men en meget ringe forudsigelighed om udfaldet. På tilsvarende måde ligger den problemløsende samtales kommunikative dyd ikke i selve talen, heller ikke i lytningen og ikke engang i deres nære forbundethed. Den ligger derimod i interaktionen mellem deltagerne og den vedvarende mulighed for, at hvert udsagn kan blive revideret under hensyntagen til den andens udspil og svar.

Dette afhænger så igen af en god portion velvilje. En strid er løbet af sporet, når tvetydigheden i de enkelte udsagn tolkes på den mest fjendtlige måde. Hvis et ægtepar skændes, og den ene siger:
»Jeg kan ikke tage det mere, jeg går«, og den anden svarer: »Så du elsker mig ikke mere? Du ønsker en skilsmisse? Du forlader mig?« - så havde det dog været lige så logisk at svare: »OK, måske trænger vi begge to til at køle lidt af et stykke tid«. Bare fordi mennesker taler sammen, er der ikke nogen garanti for, at de vil drage fordel af samtalens helbredende evner. Det, der gør samtalen til et muligt redskab for demokratisk selvstyring, er ikke samtalen i sig selv, men de normer, der styrer den.

Meget kan nå at gå galt på vejen fra samtale til demokratisk ledelse. Da det forholder sig sådan, er samtalens grundregler vigtigere end den spontanitet, som den kan frembringe. Samtale kan være meget lidt egalitær, og uden passende træning, uddannelse og social lighed er dette sædvanligvis tilfældet. Reglerne for demokratisk samtale kan hjælpe med til at beskytte personer, der har svært ved at føre ordet, og som ellers ville blive umyndiggjort af de velformulerede og facile.

Det er en særdeles vanskelig opgave at tale ved et offentligt møde, og det kan gøre folk så skrækslagne, at de simpelthen udebliver. Som en landmand i byen Vermont fortalte politologen Jane Mansbridge: »Det kræver da en smule mod. Især hvis du rejser dig og begår en brøler. Altså, hvis du laver en fejl og siger noget, så får de dig ikke til at stå op og sige noget igen. Man føler sig mindreværdig« (Mansbridge, 1980: 60-64). Florence Johnson, rengøringskone og mor til fem, havde aldrig deltaget i et offentligt møde i byen, da Mansbridge talte med hende: »Hvis du tager derhen og hæver stemmen, laver de grin med dig for at sige noget og sådan, og jeg gætter på, at folk bare ikke har lyst til at tage derhen for at blive gjort til grin«. Andre mente, at de ville tale til et offentligt møde, men kun hvis de blev vrede. En pensioneret forretningsmand sagde: »Nogle mennesker er veltalende og kan få andre til at føle sig mindreværdige. De kan få dem til at lukke helt i. Jeg ville ikke sige et ord til et møde, med mindre de fik mig gjort helvedes rasende«.

Mansbridge fandt igen og igen, at der opstod store spændinger på de offentlige møder, for nogle menneskers vedkommende endog blot ved udsigten til dem. Bonden Jamie Pedley fik en dundrende hovedpine; en ældre mand frygtede for sit hjerte. Gang på gang fortalte byens indbyggere, at folk ikke ville tale ved de offentlige møder, fordi de var bange for kritik eller for at blive gjort til grin. 
Selv blandt dem, der overvandt deres frygt og deltog i offentlige møder, var lysten til at tale meget ulige fordelt. Sociale uligheder blev reproduceret og ligefrem forstærket i denne fordeling. På de tre offentlige møder, som Mansbridge fokuserede på, var eksempelvis 49 procent af deltagerne kvinder, men de udgjorde kun 29 procent af dem, der sagde noget ved møderne, og hovedparten af dem afgav kun en mundtlig rapport eller stillede spørgsmål. Kvinder stod kun for 8 procent af, hvad Mansbridge klassificerede som »større holdningserklæringer». De igangsatte ikke en eneste af de $10 »$ kontroversielle debatter .

Den frygt for at komme i forlegenhed, som borgerne i Vermont udtrykker, er en grundlæggende menneskelig egenskab. Charles Darwin argumenterede for, at alle menneskelige følelsesudtryk bortset fra ét har et sidestykke blandt andre arter. Det særlige ved menneskets følelsesudtryk er rødmen; Darwin forklarer, at det er »tanken om, hvad andre tænker om os, der får os til at rødme«. Vi rødmer med andre ord, fordi vi føler os pinligt berørt. For sociologen Erwin Goffman (1981) udgør anstrengelserne for at undgå pinlige situationer det centrale og vedvarende drama i menneskelivet. Det er ikke noget tilfælde, at det er offentlige situationer, som Goffman regelmæssigt gør til genstand for analyse. Der er situationer, hvor muligheden for at blive pinligt berørt er minimal, specielt hvor mennesker føler sig fuldstændig hjemme, eller hvor religiøs eller politisk ophidselse eller lidenskabelig forelskelse praktisk talt gør mennesker asociale, det vil sige, gør dem relativt ufølsomme over for holdninger hos overfladiske bekendtskaber eller fremmede. Men på offentlige møder, i samtaler på gadehjørner og ved andre interaktioner med bekendte i offentligheden træder fremstillingen af selvet og den dermed forbundne risiko for at komme i forlegenhed i forgrunden (Se Schudson, 1984).

Vi bør måske skelne mellem to typer af samtaler i demokratier. De er begge nødvendige for det demokratiske samfunds virke, men på radikalt forskellig måde. I den homogene samtale taler mennesker primært sammen med nogle, som de er enige med, og de forventer derfor, at samtalen vil bestyrke dem i de synspunkter, de allerede har. I sådanne samtaler kan mennesker afprøve deres synspunkter for at blive sikre i deres sag, og de kan afprøve idéer, som måske ikke vinder fuld tilslutning, men de gør det ud fra en klar viden om, at de er enige om det væsentligste, og at de holdninger, de har til fælles, vil gøre sådanne eksperimenter ufarlige. I sådanne familiære samtalesituationer kan mennesker forberede sig på den mere dristige form for medborgerskab: den heterogene samtale. I sådanne »ægte offentlige« samtaler, som vi kan kalde dem, taler borgere med andre borgere, som de ikke deler synspunkter eller værdier med. I disse samtaler er der ingen mulighed for venskabelig afprøvning; i sådanne situationer straffes man for at udtrykke usikkerhed og tvivl, og man belønnes for at tale med overbevisning og sikkerhed. Temperamenter kan blusse op, og arbejdsfællesskaber kan blive tyndslidte eller gå i stykker. Men der er også mulighed for at blive opløftet over at nå til en overenstemmelse (eller for den ene eller anden af parterne til at opnå indrømmelser) og til trods for heterogenitetens vanskeligheder at få ordnet de offentlige anliggender. ${ }^{5}$

Det er specielt i de ægte offentlige samtaler, at man påkalder sig normer for fornuft. Eksempelvis argumenterer Stephen Macedo (1990) for, at i et demokrati må meningsdannelse »til et vist mål have ræsonnementets form og kvalitet«, hvis de vil gøre krav på offentlig betydning. Som minimum "må borgerne underbygge deres politiske handlinger med offentlige begrundelser og argumenter. Disse offentlige begrundelser må yderligere disciplineres gennem kontakt med de fornuftige $o g$ forsvarlige sider af vores forfatning og juridiske tradition« (Macedo, 1990: 103). Macedo er opsat på at vise, at liberalisme er forenelig med en stærk opfattelse af medborgerskab, dvs. én der fordrer visse dyder og fremgangsmåder som forudsætning for medborgerskab. »Borgernes deltagelse bør præges af det offentlige forsvars ånd: de skal ikke kun fremsætte deres eget synspunkt, men overveje og forholde sig til fornuftige argumenter, der fremføres af andre, inklusive offentlige embedsmænd «. Liberalisme står ikke alene for fordragelighed, frihed styret af loven og en opfattelse af retfærdighed baseret på rettigheder, men også for »selvstyre gennem fornuft«. Det sidste indebærer en insisteren på, at vi behandler hinanden rimeligt og møder indvendinger »med ræsonnementer« - det er en »aspiration om offentlig fornuft« (Macedo, 1990: 40).

Macedos opfattelse adskiller sig fra såvel den selskabelige som den problemløsende samtalemodel, som jeg har beskrevet. I modsætning til det selskabelige synspunkt er den højtidelig til det ked- 
sommelige med sin alvorstunge forestilling om en samtale, der er forpligtet på de højeste fælles mål $o g$ anvender den offentlige morals strengeste normer. Her har æstetik, leg og vid ingen plads. På samme tid adskiller dette synspunkt sig fra enhver model, der lægger stor vægt på samtalens spontanitet. Samtalen, som Macedo forestiller sig den, er ikke spontan, veltalende eller fritløbende i det uendelige. Den er hårdt arbejde. Dens fortrin ligger mindst lige så meget $\mathrm{i}$ forberedelsen til samtalen som i noget, der spontant måtte opstå i den, eller endnu mindre i noget, der kan fuldbyrdes i selve diskussionen.

Sådan forholder det sig også med den juridiske teoretiker Bruce Ackerman. Han mener, at »dia$\log$ «er »medborgerskabets første forpligtelse« (Ackerman, 1989: 6). Ackermans synspunkt medfører - korrekt efter min opfattelse - at liberalisme ikke er funderet i et »liberalt subjekt«, altså et rationelt, autonomt individ, forpligtet på videnskabelig rationalitet og dermed impliceret i en hvid, mandlig middelklassemoral. Liberalisme er et system, der er skabt til at bistå socialt konstituerede personer, der vitterligt på en måde konstruerer sig selv socialt, mennesker der påtager sig forskellige roller, som er forskellige »subjekter« og jeg'er i forskellige situationer. I offentlige politiske sammenhænge vil disse personer udelade eller aktivt undertrykke sider af dem selv. De passer ikke til liberalismen, fordi de er skabt til at passe ind i den; de passer til den, fordi de har forpligtet sig til at få den til at virke.

Normer for fornuft som dem, Macedo forestiller sig, passer ikke til en hvilken som helst samtale. Tænk på Grice's regler for samtale, som Habermas tager i anvendelse i sin pragmatik for samtale. Det er samarbejdsregler, snarere end regler for ræsonneren. De forudsætter i mindre grad en orientering mod det logiske og i højere grad en social forpligtelse, en villighed - indtil videre - til at underordne enhver personlig dagsorden under den øjeblikkelige opgave: at videreføre selve talen. Tale er, som Erwin Goffman skriver, »et eksempel på det arrangement i hvilket individer mødes og opretholder anliggender, der har et stadfæstet, fælles, gængs og løbende krav på opmærksomhed, et krav der fører dem sammen i en slags intersubjektiv, mental verden«(Goffman, 1981: 70-71). Dette er samtale defineret på en meget omfattende måde, men den specificerer ikke de betingelser, der er nødvendige for at have den slags samtale, som demokrati-teoretikere plæderer for.
Mange samarbejdende samtaler er vellykkede, men mangler et demokratisk ideal. I et kort skuespil med titlen »En lille smerte« beskriver Harold Pinter en samtale ved morgenbordet mellem Flora og Edward. Som vi måske kunne forvente, læser Edward avis, da scenen begynder, men det lykkes Flora at få ham inddraget i samtalen:

Flora: Har du set kaprifolierne til morgen?

Edward: Set hvad?

Flora: Kaprifolierne.

Edward: Kaprifolier? Hvor?

Flora: Ved lågen i baghaven, Edward.

Edward: Er det kaprifolier? Det troede jeg var-snerler eller sådan noget i den retning.

Flora: Men du ved da godt, det er kaprifolier.

Edward: Jeg siger dig jo, jeg troede, det var snerler.

(Pause)

Flora: De blomstrer noget så vidunderligt.

Edward: Jamen, det må jeg da ned og se.

Flora: Hele haven står i blomst her til morgen. Klematissen. Snerlerne. Alt. Jeg var ude allerede klokken syv. Jeg stod nede ved dammen.

Edward: Sagde du, at --- snerlerne blomstrede? Flora: Ja.

Edward: Men du gode Gud, har du ikke lige benægtet, at der var nogen?

Flora: Jeg talte om kaprifolierne.

Edward: Om ---

Flora (roligt): Edward - de buske uden for redskabsskuret---

Edward: Ja, ja.

Flora: Det er snerler.

Edward: Er det snerler?

Flora: Ja.

Edward: Hm! (Pause) Det troede jeg var japanske kirsebær.

Flora: Gud, nej.

Edward: Vær venlig at række mig thepotten. ${ }^{6}$

Selvom dette er morsomt, har det alle normalsamtalens kendetegn. Der er gensidigt engagement. Der er en upartisk og ligelig udveksling af taleture. Der er en gensidig imødekommenhed, der muliggør reparation og heling. Der er en evne til at videregive information og præcisere den fælles verden. Men samtalen fattes offentlig fornuft.

Offentlig fornuft er påkrævet, hvor der er risiko for at tabe fatningen. Samtalen er naturligvis vigtig i de behagelige situationer, hvor vi kan afklare vores holdning ved »at tænke højt«. Men den er 
også vigtig i de ubehagelige situationer, hvor vi risikerer forlegenhed, hvis vi ikke ved eller ikke kan udtrykke, hvad vi mener. I den offentlige diskussions institutioner er det faktisk de ubehagelige situationer, der dominerer. Demokratiet er dybt ubehageligt. Det er netop i situationer, der hører til det offentlige demokrati, at vi finder den Goffman'ske verden præget af hændervridende ængstelighed.

\section{Samtalens emne}

Hvad er så emnet for den problemløsende offentlige samtale i et demokrati? I den selskabelige model opfattes samtalens emne nærmest som irrelevant bortset fra at den ikke må omhandle noget, der er så alvorligt, at det ødelægger den gode stemning. Den problemløsende samtale er mere ambitiøs og mere modsætningsfyldt. Den insisterer på et vist mål af selskabelighed eller i det mindste høflighed, men også på evnen til at løfte det selskabelige ud i offentligheden. Dette fører samtidig det offentlige ind i det selskabelige. Den demokratiske samtale er delvist afhængig af og lever som en snylter på en allerede eksisterende offentlig verden - der ofte er tilgængelig i form af det trykte ord. Dette bekræfter den opfattelse, som den franske sociolog Gabriel Tarde udtrykte for et århundrede siden, nemlig at bøger og aviser udgør et næsten universelt grundlag for indholdet af private samtaler. Ikke, at enhver behøver at læse aviser, men selv de, der undlader, »er tvungne til at følge sporet af deres lånte tanker. Én pen er tilstrækkelig til at få en million tunger på gled « (Tarde, 1898/1969: 304). Tarde mener, at før bogtrykkets opfindelse varierede samtaler stærkt fra det ene sted til det andet og havde kun monotonien til fælles. Men med bøger og i særdeleshed pressen bliver samtaler »enartede i rum og forskelligartede i tid. Hver morgen leverer aviserne dagens samtaler til sit publikum. På ethvert tidspunkt kan man næsten med sikkerhed vide, hvad temaet er blandt mænd, der taler i en klub, i et rygeværelse eller i en lobby« (Tarde 1898/1969: 312). Avisen begyndte, tilføjer Tarde, »som kun et forlænget ekko af passiarer og brevvekslinger og endte med at blive deres næsten enerådende kilde« (Tarde 1898/1969: 317-18). Demokratiske samtaler er centreret om offentlige anliggender. Efter min opfattelse betyder det, at hvad demokratiske samtaler handler om, stammer fra offentlige kilder. Avisen er histo- risk set den afgørende kilde til den demokratiske samtale - avisen, lovene og den offentlige verden.

Megen af nutidens tænkning om medier antager, at ansigt-til-ansigt samtale er en overlegen form for menneskelig interaktion, som massekommunikation for altid vil være en mangelfuld erstatning for. Som John Dewey skrev i 1927: »samtalens levende ord i det umiddelbare samkvem har en afgørende betydning, som den skrevne tales fikserede og frosne ord mangler«. Dewey anerkendte, at det trykte ord var nødvendigt som »en forhåndsbetingelse for skabelsen af en sand offentlighed «. Alligevel »er det trykte ord og dets resultater, når alt kommer til alt, kun redskaber. Deres sluttelige aktualitet fuldføres i ansigt-til-ansigt relationer gennem den direkte gensidige udveksling « (Dewey, 1927: 218).

Dette er et forsøg på at sikre samtalens forrang over massekommunikationen, men jeg tror ikke, at det lykkes. Demokratisk tale er, når alt kommer til alt, ofte helt det modsatte af, hvad Dewey (og Carey efter ham) foreslår: det er snarere sådan, at ansigt-til-ansigt samtale fører til noget skriftligt, end at noget trykt kulminerer i en samtale. Fuldendelsen af den demokratiske tale kan være en underskreven anmodning, en afsendt bekendtgørelse, en skreven lov, en skreven juridisk erklæring, en skreven myndighedsordre. Demokratier værdsætter skriftens magt til at sikre, bekræfte og skabe offentlighed. Demokratier behøver en offentlig hukommelse; skriften forøger i høj grad den offentlige hukommelses kapacitet. Tale i et demokrati er således høflig, offentlig og orienteret mod de eksplicitte, tilgængelige og kommunikerbare meddelelser, man finder i trykte medier, radio og tv snarere end $i$ ansigt-til-ansigt samtale.

Samtale i almindelighed er det sociale livs DNA eller vækstsubstrat. Den har evnen til at reproducere sig, kombinere og overskride sig selv. Den er i sit væsen hverken offentlig eller privat, men social. Den eksisterer ikke kun i demokratier. Samtalen i demokratier kan adskille sig fra samtaler andre steder; ikke fordi demokratiet udspringer af samtalen, men fordi demokratiske politiske normer og institutioner instruerer og former samtalerne fra begyndelsen af. Der er intet i selve samtalen, der nødvendigvis fører til demokrati, end ikke dens formelle egalitarisme; i det tidlige moderne Europa signalerede den om noget aristokrati, fordi den var afhængig af dannelse.

Det er muligt, at demokratiet skaber normer, der 
påvirker selv de familiære og homogene samtaler i demokratiet. Medborgerskab siver fra det fælles politiske forum ind i de private sammenhænge. Hvor dette er tilfældet, eksempelvis i familien, bliver det vanskeligt for forælderen at besvare barnets »hvorfor skal jeg?« med et »fordi jeg siger det«. Normerne for at give begrundelser kommer her i konkurrence med antagelsen om forældreautoritet. Demokratiet skaber demokratiske samtaler, mere end samtalen naturligt skaber demokrati. Som filosoffen George Kateb har foreslået, kultiverer demokratiet en særlig type af selvet, ubemærket, ufuldstændigt, men ikke desto mindre effektivt. Den »blotte og bare status som medborger«, skriver han, som gør en person berettiget til at stille op til et valg eller til at afgive stemme, »er en kontinuerlig tilskyndelse til at kræve status som medborger... i alle ikke-politiske relationer i livet. Der er vitterligt en tilskyndelse til at politisere de ikke-politiske relationer i livet og dermed til at demokratisere dem«(Kateb, 1992: 40).

Demokratisk samtale forudsætter ikke så meget lighed og spontanitet som en normativ orden, der insisterer på lighed, og en social orden, der insisterer på et vist mål af offentlighed i talen. Det vil sige, at demokratisk samtale hverken er en samtale mellem fortrolige eller mellem fremmede, men derimod mellem borgere som er bekendte i kraft af deres medborgerskab. Fremmede vil misforstå hinanden, fordi de ikke deler den samme baggrundsviden og ikke er forpligtet på fælles normer; fortrolige vil forstå hinanden uden at tale, uden at redegøre for præmisser, uden at fremkalde potentielle konflikter og pinligheder. Demokratisk samtale er i modsætning hertil en indretning til offentlig kommunikation underlagt normer for offentlig fornuft og ikke blot en indretning til social interaktion.

Den selskabelige tale føres i klubber og kaffehuse mellem socialt ligeværdige, men ikke nødvendigvis fortrolige. Det er mere vanskeligt at få hold på, hvor den demokratiske samtale finder sted. Den kan godt finde sted mellem fortrolige i en familie i en diskussion af værdier. Men som jeg har foreslået, finder den fuldt offentlige demokratiske samtale sted i situationer, hvor talen må blive ubehagelig. Det er denne type tale, som folk er lede ved at deltage $\mathrm{i}$ - den indbyder til konflikt, og uanset om det er i en lille by som Vermont eller et andet sted, foretrækker folk den selskabelige samtale fremfor den potentielt eksplosive samtale. ${ }^{7}$ Tale af denne slags er så meget en trussel, at den fordrer formelle eller uformelle regler for deltagelse. Se for eksempel på de regler, der blev fastsat for tale ved det forfatningsgivende konvent, De Forenede Staters »ur-samtale«.

Fredag den 25. maj 1787 holdt det forfatningsgivende konvent sit første møde. De indledende opgaver blev resolut ordnet - George Washington blev valgt til præsident for konventet, og en komité blev udpeget til at forberede regler for proceduren. Blandt de regler, som komitéen foreslog, indgik, at når et medlem af konventet talte på mødet, måtte de andre medlemmer ikke tale med hinanden »eller læse i en bog, pamflet eller avis, det være sig trykt eller håndskreven«. Ingen måtte tale mere end to gange vedrørende det samme spørgsmål uden særlig tilladelse, og man kunne alene tale for anden gang, hvis alle andre, der ønskede ordet, fik en tilsvarende mulighed. Disse regler for ligelig respekt og lige muligheder for deltagelse blev suppleret med regler, der skulle tilskynde til en nøje overvejelse af problemer, dvs. regler for offentlig fornuft. Et kompliceret spørgsmål kunne blive stykket op i flere på anmodning af enhver deltager. Enhver stat kunne få en afstemning udskudt til næste dag, også selvom debatten var afsluttet. Ethvert skrevent dokument, der skulle behandles, blev først læst igennem for at informere og blev dernæst debatteret afsnit for afsnit. Der blev også foreslået regler for høflighed. Ethvert medlem kunne blive kaldt til orden af ethvert andet medlem og ville så »få tilladelse til at forklare sin opførsel eller de udtryk, der blev kaldt dadelværdige«. Præsidenten kunne afgøre procedurespørgsmål uden appelmulighed eller debat.

Samtlige af komitéens foreslåede regler blev mødt med bred tilslutning - bortset fra én: der var indvendinger imod forslaget om, at ethvert medlem kunne kræve tilkendegivelse af ja- og nejstemmer og få dem nedfældet i mødereferatet. Rufus King fra Massachusetts mindede forsamlingen om, at konventets beslutninger ikke på nogen måde var bindende for de delegeredes vælgere, så det var unødvendigt for de delegerede at fremvise deres stemmeafgivning for vælgerne. George Mason tilføjede, at hvis man havde en skriftlig opgørelse over stemmerne, ville det afholde medlemmerne fra at ændre deres stemmeafgivning, også selvom de havde skiftet overbevisning. Som en dreven socialpsykolog anførte han, at en registrering af stemmerne ville tvinge folk til en stadig selv-over- 
ensstemmelse, selv når fornuften havde ført dem til at skifte synspunkt. Mason tilføjede, at så ville denne registrering blive et våben i hænderne på dem, der var modstandere af konventets beslutninger. Disse indvendinger sejrede.

Jeg mener, at alt dette peger på, at det, der gør en samtale demokratisk, er ikke det frie, ligeværdige og spontane udtryk, men den lige adgang til talerstolen, den ligelige deltagelse $\mathrm{i}$ at fastlægge grundregler for diskussionen, samt et sæt grundregler, der er udformet med henblik på at tilskynde til relevant tale, opmærksom lytning, passende simplificeringer og en udbredt fordeling af taleret. Denne første amerikanske politiske samtale var omhyggeligt struktureret på en måde, så den - inden for det 18. århundredes begrænsninger i form af hvem der blev regnet for borgere - kunne være ægte deliberativ og ægte demokratisk. Den måtte derfor være alt andet end spontan.

\section{Konklusion: Samtalen i demokratiet}

Samtale giver ikke nogen magisk løsning på demokratiets problemer. Demokrati har ikke meget at gøre med intimitet og heller ikke meget at gøre med fællesskab. Det kan være ophidsende, det kan være kedeligt, det kan være angstfremkaldende, det er ofte ubehageligt. Det er sjældent, at jeg finder fornøjelse ved store forsamlingers offentlige rådslagning om at træffe beslutninger. Jeg foretrækker samtalen mellem to personer frem for store møder. Jeg foretrækker seminarer frem for store forsamlinger. Jo større gruppen er, desto mere ønsker jeg regler for deltagelsen, fordi jeg er en langsom taler. Dette er en del af det, som den romantiske forestilling om samtalen ikke forstår.

Som coda vil jeg gerne tilføje et andet forhold, som den romantiske forestilling om samtalen ikke begriber. Til tider fordrer demokratiet, at man trækker sig tilbage fra samtalen, tilbage fra fælles offentlige emner. Som Stephen Holmes har foreslået, kan demokratiet insistere på, at også talen selv begrænses. I USA førte faren for, at religiøse følelser skulle splitte og sønderlemme staten og det civile samfund til den første tilføjelse til forfatningen (The First Amendment) og til en nu 200-årig historisk tradition for gennem forfatningen at søge at holde religiøse spørgsmål uden for politisk diskussion. I en vis forstand kan demokratiet vælge at give den politiske rådslagning mundkurv på og relegere den til det civile samfund eller den private sfære. For at sikre en retsindig rådslagning kan demokratier ligefrem vælge at lukke munden på den politiske tale. Det mest velkendte eksempel på dette, som praktiseres over hele USA, er et forbud mod politisk agitation inden for en nærmere bestemt afstand til afstemningsstederne på valgdagen. Her opfattes tale som en handling, som en form for intimidering eller opnåelse af urimelig fordel. Lovgivere rundt omkring i landet har konkluderet, at afstemningens højborg bør omgærdes af en ring af politisk tavshed. Langs det sidste stykke vej mod afstemningsboksen ofres den kollektive politiske ytringsfrihed til fordel for retten til personlig overvejelse.

Endelig kan demokratiet fordre, at man opgiver høfligheden. Undertiden kræver demokratiet, at din samtalepartner ikke venter høfligt til du har talt færdigt, men ryster dig i kraven og råber: »Hør efter! Så hør dog for Guds skyld efter!« Vi kalder disse situationer for sociale bevægelser, strejker, demonstrationer. De mennesker, der lægger afstand til høfligheden, kalder vi målrettede, ambitiøse, urimelige, selviske, uhøflige, hidsige, selvoptagne - det er folk som Newt Gingrich, Martin Luther King og William Lloyd Garrison. Det er alle folk, der er villige til at tage del i en demokratisk samtale, men de er også stridbare hinsides det høflige og villige til helt at stå af samtalen, i det mindste midlertidigt og strategisk, for at få deres sag frem. Ethvert udviklet begreb om demokrati og samtalens placering heri må kunne gøre rede for de tilfælde, hvor samtalen i sig selv er en hindring for demokratiets indfrielse.

\section{Noter}

1. Denne definition er bearbejdet efter A. D. Lindsay i Holmes (1995: 71).

2. Burke (1995: 106) der citerer en vejledning fra 1672 skrevet af Charles Sorel.

3. Også Gabriel Tarde understreger, at samtalen ikke er nytteorienteret. Han definerer den som »enhver dialog uden direkte eller umiddelbar nytte, i hvilken man primært taler for at tale, for glæden, som en spil, ud af høflighed « (Tarde, 1898/1969: 308). Dette uddrag kommer fra Tardes »L'opinion et la foule « (Paris, Alcan, 1922: 62-158), men det blev første gang publiceret i Revue de Paris i 1898. Se redaktørens note i Tarde (1898/1969: 297).

4. Oakeshott har antagelig ikke brug for eksperter: der er ikke nogen opfattelse af, at man behøver »ekspertise« for at deltage i en samtale; det er nødvendigt at være kultiveret, men det er noget ganske andet. Men hvis 
Oakeshott ikke forsvarer ekspertise, er Dewey (1927: 206) ganske direkte en kritiker af den: »Det er umuligt for de intellektuelle at fastholde et monopol på den type viden, der skal bruges til at regulere de fælles anliggender. I det omfang, de udvikler sig til en specialiseret klasse, afskæres de fra viden om de behov, som det er meningen, de skal tjene«.

5. Jeg har udviklet denne skelnen på baggrund af forslag fra Elihu Katz.

6. Jeg brugte dette citat for nogle år siden i en tidligere og ganske anden bestræbelse på at forstå samtalens betydning for vores tænkning om massemedier og - som sekundær bestræbelse - om demokratiet. (Se Schudson 1978: 320-329).

7. Som det var tilfældeti begyndelsen af dette århundrede, kan offentlig politisk tale endog blive hånet for at finde sted i gadens støjende rum snarere end i det borgerlige hjem. En avis fra New Jersey roste de »stille, tænkende mænd [...], der dag efter dag i al stilfærdighed arbejder på at tjene til livets ophold, og som om natten befinder sig i hjemmet i stedet for at diskutere politik på gadehjørnerne« (Trenton True American, 6. november 1911, citeret i Reynold (1988: 120)).

\section{Litteratur}

Ackerman, B. (1989)»Why a dialogue?«, in fournal of Philosophy, 86, p. 5-22.

Burke, P. (1995) The art of conversation, Cambridge: Polity Press.

Carey, J. (1987, marts/april) »The press and public discourse«, The Center Magazine, p. 4-16.

Carey, J. (1989) Communication as culture, Boston: Unwin Hyman.

Carey, J. (1995) »The press, public opinion, and public discourse«, in T. Glasser \& C. Salmon (red.) Public opinion and the communication of consent, p.373-402, New York: Guildford.

Dewey, J. (1927) The public and its problems, New York: Henry Holt.

Galston, W. (1991) Liberal purposes, Cambridge: Cambridge University.

Goffman, E. (1981) Forms of talk, Philadelphia: University of Pennsylvania.

Grice, P. (1989) »Logic and conversation« (1975), in P. Grice: Studies in the way of words, Cambridge, MA: Harvard University.
Habermas, J. (1974) »The Public Sphere«, New German Critique, 1, p. 49-55.

Holmes, S. (1995) Passions and constraint, Chicago: University of Chicago.

Kateb, G. (1992) The inner ocean, Ithaca, NY: Cornell University.

Macedo, S. (1990) Liberal virtues: Citizenship, virtue, and community in liberal constitutionalism, Oxford: Clarendon.

Mansbridge, J. (1980) Beyond adversary democracy, New York: Basic Books.

Oakeshott, M. (1962) »The voice of poetry in the conversation of mankind «, in M. Oakeshott Rationalism in politics, New York: Basic Books.

Pinter, H. (1961)»A slight Ache«, in Three plays, New York: Grove. Her citeret fra den danske udgave fra 1974: En lille smerte, oversættelse: Anna Kathrine Gudme, København: TV-teaterafdelingen i Danmarks Radio.

Reynolds, J. (1988) Testing democracy, Chapel Hill: University of North Carolina.

Schudson, M. (1978) »The ideal of conversation in the study of mass media«, in Communication Research, vol. 5, no. 3, juli 1978, p. 320-329.

Schudson, M. (1984) »Embarrassment and Erving Goffman's idea of human nature«, in Theory and Society, 13, p. 633-648.

Shapin, S. (1994) A Social History of Truth, Chicago: University of Chicago.

Simpson, D. (1995) The academic postmodern and the role of literature, Chicago: University of Chicago.

Simpson, D. (1997) »The cult of »conversation««, Raritan, 16 , p. $75-85$.

Tarde, G. (1898/1969) On communication and social influence (redaktion og oversættelse: T. Clark), Chicago: University of Chicago.

Michael Schudson er professor i kommunikation og sociologi ved University of California, San Diego. Artiklen blev først publiceret i Critical Studies in Mass Communication, 14, 1997, side 297-309. MedieKultur takker forfatteren og tidsskriftet for tilladelse til at måtte bringe artiklen. 